\title{
Reasons behind the Failure of Teaching Sudan Practical Integrated National English (SPINE 5) in Sudan
}

\author{
Mona M. Hamad \\ ${ }^{1}$ Department of English Language, College of Science \& Arts, Muhayil, King Khalid University, Saudi Arabia \\ Correspondence: Mona M. Hamad, Department of English Language, College of Science \& Arts, Muhayil, King \\ Khalid University, Saudi Arabia. Tel: 966-542-349-145. E-mail: monahamed65@hotmail.com, \\ mmabdulaziz1@kku.edu.sa
}

Received: November 5, 2014 Accepted: December 8, $2014 \quad$ Online Published: January 20, 2015

doi:10.5539/elt.v8n2p143 URL: http://dx.doi.org/10.5539/elt.v8n2p143

\begin{abstract}
According to the development of English language learning and curriculum design, English language series became a very important issue that affects education globally and in Sudan in specific, this study reports reasons behind the failure of teaching SPINE 5 (which is one of SPINE series) from the teachers' point of view in Bahry Locality in Sudan, 100 questionnaire papers were designed and distributed to English Language teacher in Bahry Locality, 83 of them were filled and returned, the questionnaires papers were analyzed using descriptive and analytical research methods using SPSS to find reasons behind the failure of Teaching SPINE 5 to help curriculum designers in Sudan find solution to these problems, the questionnaire is divided to six domains, 1) Teachers, 2) Pupils, 3) Curriculum and Textbook, 4) Teaching methods, 5) Activities, 6) Teaching and learning environment. The main findings of the study were 1) English language teachers are not specialized and not qualified enough to cope with SPINE 5. 2) Most of the English Language teachers do not refer to the teacher's book to teach the four skills in their lessons plan. 3) Most of the teachers are not aware of the concept of integrated English curriculum as mentioned in SPINE series, and the book title doesn't reflect its content. 4) Most of the teachers do not attend and observe lessons to other teachers in their school and need training. 5) SPINE 5 Textbook is too long to be covered in one academic school year, and its layout is not logical or attractive, moreover, it doesn't widen students' knowledge about western culture. 6) The four skills (listening, speaking, reading and writing) are sometimes taught separately and the same class is taught by more than one teacher, each teaches different skills. 7) No supplementary materials or teaching aids are used to teachSPINE 5. 8) Pupils background of English is weak and their seating is not comfortable and the classrooms are crowded, so it is too difficult to use communicative competence to develop their acquisition of language. It has been strongly recommended: 1) Employing English language teachers must be according to their qualifications, and a regular training programme should be set to train English Language teachers to make them aware about what is new in the pedagogy world. 2) Every pupil must be provided with a copy of SPINE 5 book in the beginning of the academic year to enable teachers and pupils achieve their tasks. 3) Teaching English language should be through British culture, according to the British environment not ours, and develop teachers' language and ability within British culture training by sending teachers to England to have reinforcing courses in the English heritage not Sudanese or by organizing courses to be taught by British teachers with the collaboration with the British Council in Sudan. 4) Class-room must not consist of more than 40 students to help using communicative approach. 5) Raise the number of English periods to 6-7 periods a week instead of 5.
\end{abstract}

Keywords: reasons, failure, practical, integrated

\section{Introduction}

\subsection{Introduction of the Problem}

English is a widespread and important language in the world today. It is used for everything from international academic conferences to news reports, books, popular music, lyrics and desired higher degree education, add to that it is the ultimate method of communication between native speakers and non-native speakers of English language. English language is used in Sudan as a Second Language (ESL) and it is a compulsory subject to sit for Sudan Secondary Certificate (S.S.C) which qualifies students to enroll in universities. English Curricula have been change many times since 1970, but in 1989 not only was the English curriculum changed, but also the 
education ladder, to be 11 years ( 8 years basic level +3 years secondary level) instead of 12 years $(6$ years basic level +3 years intermediate level +3 years secondary level) - (Sudan Ministry of Education Report, 2009). Again in 1992 SPINE series (Sudan Practical Integrated National English) were introduced and English language started to be taught from the $5^{\text {th }}$ grade at basic school instead of the first year intermediate level, however, the standard of English Language continue to decline steadily, although the Sudan Practical Integrated National English (SPINE) series has been designed to have the four skills taught in the Sudanese schools integrity, as the authors of the Secondary SPINE series (Ismail \& Cuther, 1997) \& (AlmusbahBabikir et al.) claimed that "The SPINE series integrate the four skills so that each skill supports the others: It (the series) features the best of... communicative language teaching ... Creating interactive, learner-centered activities... The central aim of the SPINE series is to enable the pupils to use English freely, naturally and fluently"...SPINE aims to motivate and arouse the pupils' interests and leads to make learning both effective and meaningful. SPINE encourages teachers to design learning opportunities to enable their pupils to become active, participants in a communication process".

The author of this study, who used to teach SPINE seriesat secondary level for the last twelve years noticed that the aims of SPINE series are not achieved, and nobody would claim that the central aims of SPINE which are indicated above are achieved. The rate of failure in English in the Sudanese Secondary School Exam in 2008 has been as high as $21 \%$ although the exam content is copied from SPINE text books. Furthermore, there are general indicators, that students who finish the $6^{\text {th }}$ textbooks of SPINE series can hardly write a paragraph or speak English freely, naturally and fluently, even the most talented students cannot speak or write English out of the need for their study, add to that the results of English Language Exams in Sudan Secondary Certificate (S.S.C) are characterized by deterioration, These results reflect "poor English or no English at all." (Al Busiri, 2008) this steep decline in English language has been the concern of parents; teachers, students and experts , and raised the problem of this paper which can be answered by finding out the reasons behind the failure of teaching SPINE 5 in Bahry Locality. The hypothesis of this paper is "there may be differences between the opinion of the teachers about SPINE 5 integrity", and by answering the following questions: What are the reasons behind the failure of teaching SPINE 5 in Bahry Locality relating the teachers? /pupils? /curriculum and textbook? /teaching method \& exercises? /activities? /teaching and learning environment?

\subsection{Literature Review}

The title ofSudan Practical Integrated National English series declare that the content of this book series is integrated, the concept of integrating curriculum is nothing new. It's been around, in fact, since the 1800s and was advocated by such well-known educational theorists as John Dewey and Meredith Smith. Beane (1977) who defined integrated curriculum: It is a way to teach students to break down barriers between subjects and make learning more meaningful to students. The idea is to teach around themes or "organizing centers" that students can identify with, such as "The Environment", "Life in School", or more traditional areas like "Myths and Legends".

Also Humphreys (1981) defined integrated curriculum "interdisciplinary teaching, thematic teaching, synergistic teaching... An integrated study is one in which children broadly explore knowledge in various subjects related to certain aspects of their environment".

Shoemaker (1989) defines an integrated curriculum as "education that is organized in such a way that it cuts across subject-matter lines, bringing together various aspects of the curriculum into meaningful association to focus upon broad areas of study. It views learning and teaching in a holistic way and reflects the real world, which is interactive".

According to the previous definition and SPINE 5 authors claims that mentioned before it supposed that by learning SPINE 5 the students would master the four skills in real life by integration of the language skills in the class room, and they will perceive the relation between the fours skills. Moreover this textbook will provide the teacher with flexibility in creating motivating lessons and make them creative and not plod alone one mode of performance' skill, which helps the teacher and gives him or her the chance to use the appropriate approach or method to reach his or her goal.

\subsection{Previous Studies}

Mahasin Dafalla Mohamed Alhag (2000) reported thatuniversity students in Sudan are not exposed to using spoken English outside the lecture's room because there is no real situation for conversation, and overcrowded classes in general education in the Sudan hinder the students from practicing the oral language before university.

Ahmed Gumaa Siddiek (2001) suggests abolishing all colleges of education and encouraging the future teacher 
to join a one-year training course after she/he has got his/her BA or B.Sc. to develop their performance to be equipped with necessary pedagogical knowledge to qualify them manage their classroom efficiently and carry out effective classroom presentation. Ishraga Bashir Mohammed Elhassan Mahgoub (2001) reported that (SPINE 3 ) is not an ideal book for basic level and the book content is not motivating beside the illustrations of SPINE 3 are not relevant or attractive and the book objectives are not defined clearly. Widad Hussein Ibrahim Mohamed (2002) stated that there is shortage of time to finish SPINE 5 during the school days while the prescribed periods of time were not adequate for practicing the four language skills properly, and due to SPINE 5 overloaded vocabulary, students' acquisition was very weak. Ahmed Guma'a Siddiek (2004) stated recent form of The Sudan School Certificate Examination (SSC),"English LanguageExamination" doesn't reflect the real performance of Sudanese students in English Language and it lack validity. Faisal Abd Erahman (2007) stated that oral proficiency is affected by lack of teachers training and assistance from their supervisors and English language syllabus is not well - organized to develop the four language skills, while the activities don't encourage sufficient communicative meaningful practice, moreover, English language tests are not well- prepared and schools conditions and educational environment is not ideal for teaching English language course and there is a lack of teaching aids. Also Mohammed Mohammed Abdella Alamin (2007) mentioned that large number of students in classes is not conductive for teaching English Communicatively while the Sudanese universities syllabus does not enable students to communicate orally.

\section{Research Methodology}

\subsection{Data Collection}

The researcher used the descriptive analytical approach to find out Reasons behind the Failure of Teaching Sudan Practical Integrated National English (SPINE 5) In Sudan, the study has been carried in Bahry locality in Sudan in theacademic year 2011-2012.

\subsection{Participants}

83 English language teacher and Supervisors of Secondary level in Bahry Locality, Sudan were the participants of this study, 43 male and 40 female.

\subsection{Study Instrument}

A. 100 questionnaire papers were distributed to English language teachers and Supervisors in Bahry Locality in Sudan in the academic year 2011-2012 (see appendix 1), 83 questionnaire papers were returned, the questionnaire were divided to six domains 1) Teachers. 2) Pupils. 3) Curriculum and Textbook. 4) English Language teaching methods and exercises. 5) Activities. 6) Teaching and learning environment.

\subsection{Validity and Reliability of the Questionnaire}

- To find the validity of the questionnaire, the following formula was applied after finding the reliability results using Cronbachs method: Validity $=\sqrt{ }$ reliability $=(0.97)$.

- It is obvious that $(0.97)$ is a high degree that reflects the teachers' questionnaire validity which indicates it is suitable to be used in the field of the study.

\section{Statistics and Data Analysis}

Questionnaire responses were manually coded and analyzed using SPSS version 10. The researcher used t-test through t-distribution table is used to find out if the results of the teacher questionnaire are significant or not which help to predict if the statements in the teacher questionnaire are true or not, this is done according to the teachers' answers and the statistical results. Below are t- distribution tables for each domain's items which will be discussed below to find the final results.

Table 1. Reasons behind the failure of teaching SPINE 5 in Sudan related to the teacher

\begin{tabular}{|c|c|c|c|c|c|c|c|}
\hline \multirow[b]{2}{*}{ No. } & \multirow[b]{2}{*}{ Questionnaire items } & \multicolumn{5}{|c|}{ Test Value $=2$} & \multirow[b]{2}{*}{ Prediction } \\
\hline & & Mean & $\begin{array}{l}\text { Std. } \\
\text { Devia-tion }\end{array}$ & $\mathrm{t}$ & $\mathrm{df}$ & $\begin{array}{l}\text { Sig (One } \\
\text {-tailed) }\end{array}$ & \\
\hline 1 & $\begin{array}{l}\text { All teachers who teach SPINE } 5 \text { are } \\
\text { specialized in English language teaching. }\end{array}$ & 1.61 & 0.839 & -4.189 & 82 & 0.001 & Significant \\
\hline 2 & $\begin{array}{l}\text { My teaching load is too much (more than } \\
18 \text { periods a week.) }\end{array}$ & 1.90 & 0.938 & -0.942 & 81 & 0.349 & Not Significant \\
\hline 3 & English Language teachers are strongly & 1.93 & 0.894 & -0.737 & 82 & 0.464 & Not Significant \\
\hline
\end{tabular}


qualified to teach SPINE 5

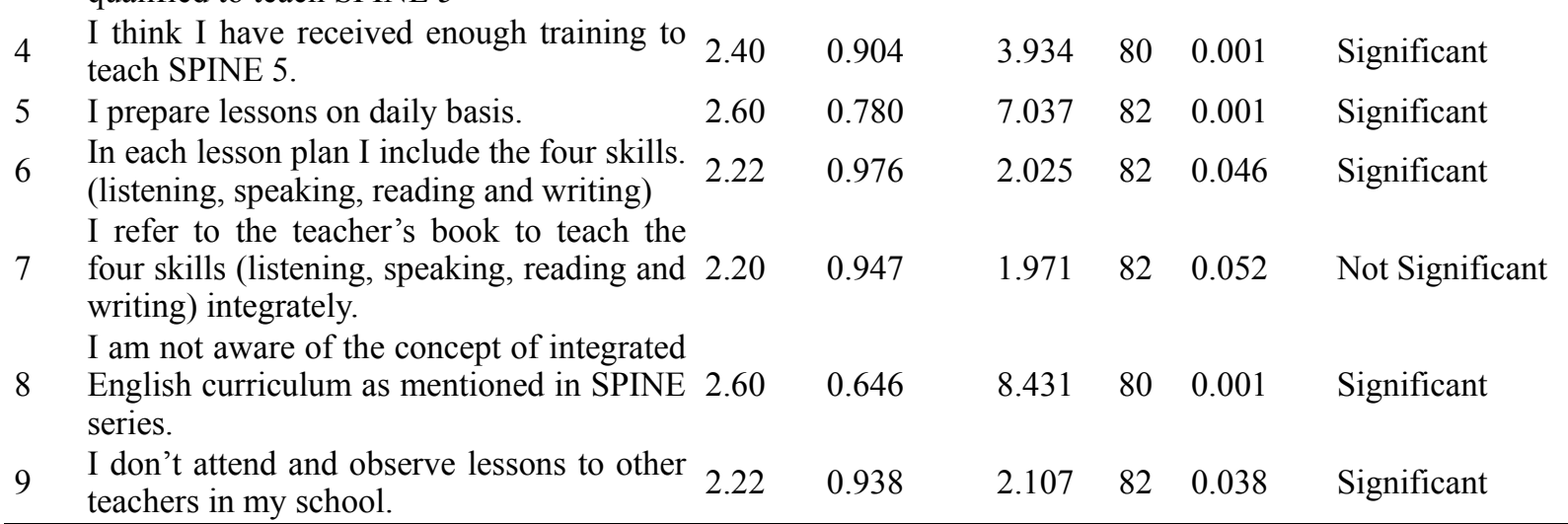

Independent sample t-test was applied to identify any significant difference in responses to teachers' questionnaire. The results in the table above reveal statements $1,4,5,6,8,9$ are allsignificant, but 1 shows low indicator because t-value is not positive, so the results which reflect the reasons behind the failure of teaching SPINE 5 In Sudanas related to the teachers are: 1) English language teachers are not specialized in teaching English Language. 2) English language teachers are not satisfied with their teaching load. 3) English Language teachers are not qualified enough to cope with SPINE 5. 4) English Language teachers think that they received enough training to teach SPINE 5. 5) English Language teachers prepare lessons on daily basis. 6) English Language teachers include the four English language skills in each lesson plan. 7) Most of the English Language teachers do not refer to the teacher's book to teach the four skills in their lessons plan. 8) Most of the teachers are not aware of the concept of integrated English curriculum as mentioned in SPINE series. 9) Most of the teachers do not attend and observe lessons to other teachers in their school.

Table 2. Reasons behind the failure of teaching SPINE 5 in Sudan related to the pupils

\begin{tabular}{|c|c|c|c|c|c|c|c|}
\hline \multirow[b]{2}{*}{ No. } & \multirow[b]{2}{*}{ Questionnaire items } & \multicolumn{5}{|c|}{ Test Value $=2$} & \multirow[b]{2}{*}{ Prediction } \\
\hline & & Mean & $\begin{array}{l}\text { Std. } \\
\text { Deviation }\end{array}$ & $\mathrm{t}$ & $\mathrm{df}$ & $\begin{array}{l}\text { Sig (One } \\
\text {-tailed) }\end{array}$ & \\
\hline 10 & Pupils' background in English is weak. & 2.55 & 0.500 & 10.097 & 82 & 0.001 & Significant \\
\hline 11 & $\begin{array}{l}\text { Pupils find learning English language } \\
\text { through SPINE } 5 \text { textbook interesting. }\end{array}$ & 1.81 & 0.671 & -2.617 & 82 & 0.011 & Significant \\
\hline 12 & $\begin{array}{l}\text { Pupils can read and understand English } \\
\text { newspapers and simplified stories by } \\
\text { themselves. }\end{array}$ & 1.20 & 0.488 & -14.849 & 82 & 0.001 & Significant \\
\hline 13 & $\begin{array}{l}\text { Pupils are encouraged to speak with each } \\
\text { other in English language outside the } \\
\text { class room. }\end{array}$ & 1.35 & 0.633 & -9.362 & 82 & 0.001 & Significant \\
\hline 14 & $\begin{array}{l}\text { Pupils write correct sentences and } \\
\text { paragraphs without help. }\end{array}$ & 1.35 & 0.504 & -11.750 & 82 & 0.001 & Significant \\
\hline 15 & $\begin{array}{l}\text { Pupils listen and understand the } \\
\text { dialogues in SPINE 5. }\end{array}$ & 2.07 & 0.620 & 1.061 & 82 & 0.292 & Not Significant \\
\hline 16 & $\begin{array}{l}\text { Pupils receive help from their parents at } \\
\text { home to practice English with them. }\end{array}$ & 1.47 & 0.526 & -9.184 & 82 & 0.001 & Significant \\
\hline 17 & $\begin{array}{l}\text { Pupils can understand a foreigner who } \\
\text { speaks with them in English. }\end{array}$ & 1.27 & 0.444 & -15.079 & 82 & 0.001 & Significant \\
\hline 18 & Pupils use English freely and naturally. & 1.19 & 0.454 & -16.192 & 82 & 0.001 & Significant \\
\hline 19 & $\begin{array}{l}\text { Pupils are able to practice English with } \\
\text { people outside the school. }\end{array}$ & 1.25 & 0.437 & -15.559 & 82 & 0.001 & Significant \\
\hline
\end{tabular}

After applying the independent sample t-test to identify any significant differences in the responses to the teacher questionnaire concerning the pupils' domain, the results of all statement are significant except statement number 15, but all statement show low indicators because t-value is not positive which mean. 10) Pupils' background in English is weak. 11) Pupils don't find learning English language through SPINE 5 textbook interesting. 12) 
Pupilscan't read and understands English newspapers and simplified stories by themselves. 13) Pupils are not encouraged to speak with each other in English language outside the class room. 14) Pupils don't write correct sentences and paragraphs without help. 16) Pupils don't receive help from their parents at home to practice English with them. 17) Pupils can't understand a foreigner who speaks with them in English. 18) Pupils use English freely and naturally. 19) Pupils are not able to practice English with people outside the school, and item 15 is not significant which means pupils don't listen and understand the dialogues in SPINE 5.

Table 3. Reasons behind the failure of teaching SPINE 5 in Sudan related to the curriculum and textbook

\begin{tabular}{|c|c|c|c|c|c|c|c|}
\hline \multirow[b]{2}{*}{ No. } & \multirow[b]{2}{*}{ Questionnaire items } & \multicolumn{5}{|c|}{ Test Value $=2$} & \multirow[b]{2}{*}{ Prediction } \\
\hline & & Mean & $\begin{array}{l}\text { Std. } \\
\text { Deviation }\end{array}$ & $\mathrm{t}$ & $\mathrm{df}$ & $\begin{array}{l}\text { Sig (One } \\
\text {-tailed) }\end{array}$ & \\
\hline 20 & $\begin{array}{l}\text { English language SPINE } 5 \text { textbooks are } \\
\text { available for all pupils. }\end{array}$ & 1.74 & 0.919 & -2.539 & 80 & 0.013 & Significant \\
\hline 21 & $\begin{array}{l}\text { Teachers make some changes in Spine } \\
\text { textbook to suit their pupils'needs or } \\
\text { standard }\end{array}$ & 2.47 & 0.726 & 5.815 & 80 & 0.001 & Significant \\
\hline 22 & $\begin{array}{l}\text { Textbook SPINE } 5 \text { is too long to be } \\
\text { covered in one school academic year. }\end{array}$ & 2.67 & 0.718 & 8.567 & 82 & 0.001 & Significant \\
\hline 23 & SPINE 5 is logically organized. & 1.92 & 0.953 & -0.807 & 82 & 0.422 & Not Significan \\
\hline 24 & The layout of SPINE 5 is attractive. & 1.60 & 0.869 & -4.170 & 82 & 0.001 & Significant \\
\hline 25 & $\begin{array}{l}\text { SPINE } 5 \text { widens Pupils' knowledge about } \\
\text { western culture. }\end{array}$ & 1.67 & 0.912 & -3.249 & 82 & 0.002 & Significant \\
\hline
\end{tabular}

Independent sample t-test was applied to identify any significant differences in responses, the results according to table 3 concerning the Curriculum and Textbook Domain reveals items ( 21 \& 22) are significant and t-value is positive, which means 21) Teachers make some changes in Spine textbook to suit their pupils'needs or standard 22) Textbook SPINE 5 is too long to be covered in one school academicyear, but 20, $24 \& 25$ are significant but $\mathrm{t}$-value is not positive which means 20. English language SPINE 5 textbooks are not available for all pupils. 24) The layout of SPINE 5 is not attractive. 25) SPINE 5 doesn't widen pupils' knowledge about western culture. While 23 is not significant and t-value is not positive which means SPINE 5 is not logically organized

Table 4. Reasons behind the failure of teaching SPINE 5 in Sudan related to teaching method

\begin{tabular}{|c|c|c|c|c|c|c|c|}
\hline \multirow[b]{2}{*}{ No. } & \multirow[b]{2}{*}{ Questionnaire items } & \multicolumn{5}{|c|}{ Test Value $=2$} & \multirow[b]{2}{*}{ Prediction } \\
\hline & & Mean & $\begin{array}{l}\text { Std. } \\
\text { Deviation }\end{array}$ & $\mathrm{t}$ & df & $\begin{array}{l}\text { Sig (One } \\
\text {-tailed) }\end{array}$ & \\
\hline 26 & $\begin{array}{l}\text { Teachers use English only to teach the } \\
\text { lessons. }\end{array}$ & 2.22 & 0.750 & 2.635 & 82 & 0.010 & Significant \\
\hline 27 & Teachers teach every page in the book. & 1.99 & 0.804 & -0.137 & 82 & 0.892 & Not Significant \\
\hline 28 & $\begin{array}{l}\text { Teachers use mixture of English and } \\
\text { Arabic in teaching. }\end{array}$ & 2.36 & 0.691 & 4.765 & 82 & 0.001 & Significant \\
\hline 29 & $\begin{array}{l}\text { Cassettes are used in teaching, listening } \\
\text { and speaking skills. }\end{array}$ & 1.16 & 0.402 & -18.806 & 80 & 0.001 & Significant \\
\hline 30 & $\begin{array}{l}\text { The four skills (listening, speaking, } \\
\text { reading and writing) are taught } \\
\text { separately. }\end{array}$ & 1.64 & 0.691 & -4.765 & 82 & 0.001 & Significant \\
\hline 31 & $\begin{array}{l}\text { The same class is taught by more than } \\
\text { one teacher, each teaches different skills. }\end{array}$ & 1.58 & 0.607 & -6.326 & 82 & 0.001 & Significant \\
\hline
\end{tabular}

After applying the independents Sample t-test to identify any significant differences in the responses to the teacher questionnaire concerning teaching methods domain, the result of all statement are significant except 27. was not significant which means teachers don't teach every page in the book, moreover, only 26 is significant and t-value is positive which means Teachers use English only to teach the lessons, however 28, 29, 30, 31 t-value is not positive which means their indicators are low so the results show 28) Teachers use mixture of English and Arabic in teaching. 29) Cassettes are sometimes are used in teaching listening and speaking skills. 
30) The four skills (listening, speaking, reading and writing) are sometimes taught separately. 31) The same class is taught by more than one teacher, each teaches different skills.

Table 5. Reasons behind the failure of teaching SPINE 5 in Sudan related to activities

\begin{tabular}{|c|c|c|c|c|c|c|c|}
\hline \multirow[b]{2}{*}{ No. } & \multirow[b]{2}{*}{ Questionnaire items } & \multicolumn{5}{|c|}{ Test Value $=2$} & \multirow[b]{2}{*}{ Prediction } \\
\hline & & Mean & $\begin{array}{l}\text { Std. } \\
\text { Deviation }\end{array}$ & $\mathrm{T}$ & df & $\begin{array}{l}\text { Sig (One } \\
\text {-tailed) }\end{array}$ & \\
\hline 32 & $\begin{array}{l}\text { Activities such as acting, role-play, songs } \\
\text { and language games form integrate part of } \\
\text { the lesson. }\end{array}$ & 2.49 & 0.805 & 5.487 & 81 & 0.001 & Significant \\
\hline 33 & Conversation is practiced in class. & 2.68 & 0.664 & 9.308 & 81 & 0.001 & Significant \\
\hline 34 & $\begin{array}{l}\text { Teachers let the pupils work in pairs /small } \\
\text { groups during the lesson periods. }\end{array}$ & 2.57 & 0.786 & 6.602 & 81 & 0.001 & Significant \\
\hline 35 & Teachers give home work for the Pupils. & 2.94 & 0.328 & 25.953 & 81 & 0.001 & Significant \\
\hline 36 & $\begin{array}{l}\text { Pupils are encouraged to learn by } \\
\text { themselves. }\end{array}$ & 2.60 & 0.736 & 7.395 & 80 & 0.001 & Significant \\
\hline 37 & $\begin{array}{l}\text { Pupils are allowed to correct each other's } \\
\text { work. }\end{array}$ & 2.29 & 0.923 & 2.872 & 81 & 0.005 & Significant \\
\hline 38 & $\begin{array}{l}\text { Each Pupil is allowed tohave his/her own } \\
\text { written work corrected. }\end{array}$ & 2.12 & 0.954 & 1.165 & 80 & 0.247 & Not Significant \\
\hline 39 & $\begin{array}{l}\text { Topics are assessed for free writing } \\
\text { assigned. }\end{array}$ & 2.30 & 0.887 & 3.008 & 80 & 0.004 & Significant \\
\hline 40 & $\begin{array}{l}\text { Outside class activities are usually } \\
\text { arranged by the teacher. }\end{array}$ & 2.27 & 0.903 & 2.689 & 81 & 0.009 & Significant \\
\hline
\end{tabular}

After applying the independent Sample t-test to identify any significant differences in the responses to the teacher questionnaire concerning the activities' domain, the result of all statement are significant and t-value is positive, which means 32) Activities such as acting, role-play, songs and language games form integrate part of the lesson. 33) Conversation is practiced in class. 34) Teachers let the pupils work in pairs/small groups during the lesson periods. 35) Teachers give home work for the pupils. 36) Pupils are encouraged to learn by themselves. 37) Pupils are allowed to correct each other's work. 40) Outside class activities are usually arranged by the teacher. But 38) Result was not significant which means each pupil is not allowed to have his/her own written work corrected.

Table 6. Reasons behind the failure of teaching SPINE 5 in Sudan related to teaching and learning environment

\begin{tabular}{|c|c|c|c|c|c|c|c|}
\hline \multirow[b]{2}{*}{ No. } & Questionnaire items & \multicolumn{5}{|c|}{ Test Value $=2$} & \multirow[b]{2}{*}{ Prediction } \\
\hline & $\begin{array}{l}\text { Teaching and Learning environment } \\
\text { Domain }\end{array}$ & Mean & $\begin{array}{l}\text { Std. } \\
\text { Deviation }\end{array}$ & $\mathrm{T}$ & df & $\begin{array}{l}\text { Sig (One } \\
\text {-tailed) }\end{array}$ & \\
\hline 41 & Pupils seating is not comfortable. & 2.38 & 0.629 & 5.401 & 77 & 0.001 & Significant \\
\hline 42 & $\begin{array}{l}\text { The classroom is too crowded to allow } \\
\text { free activities. }\end{array}$ & 2.39 & 0.771 & 4.494 & 79 & 0.001 & Significant \\
\hline 43 & $\begin{array}{l}\text { Teaching aids such as: pictures, films, } \\
\text { filmstrips, tapes, charts, posters and } \\
\text { flashcards are available. }\end{array}$ & 1.20 & 0.513 & -13.945 & 79 & 0.001 & Significant \\
\hline 44 & $\begin{array}{l}\text { Audio visual aids are usually used in } \\
\text { English classes. }\end{array}$ & 1.33 & 0.591 & -10.224 & 79 & 0.001 & Significant \\
\hline 45 & $\begin{array}{l}\text { I write supplementary materials to } \\
\text { SPINE 5. }\end{array}$ & 1.93 & 0.632 & -1.062 & 79 & 0.292 & Not Significant \\
\hline 46 & $\begin{array}{l}\text { It is too difficult to use communicative } \\
\text { competence in large classes. }\end{array}$ & 2.53 & 0.693 & 6.775 & 79 & 0.001 & Significant \\
\hline 47 & Each Pupil has his own desk and chair. & 2.05 & 0.913 & 0.490 & 79 & 0.625 & Not Significant \\
\hline
\end{tabular}

After independent sample t-test was applied to identify any significant differences in responses concerning teaching and learning environment domain, the results according to Table 6 . Reveals items 44, 47 are not significant 44 . Teachers do not write supplementary materials to SPINE 5, and 47. ShowsthatPupils seating is not 
comfortable which the same result of 41 . Which is significant with positive value, also 46 ? Result is significant with positive t-value. It is too difficult to use communicative competence in large classes, the rest of the domain items are significant, so the results as follow 42. The classroom is too crowded to allow free activities. 43) Teaching aids such as: pictures, films, filmstrips, tapes, charts, posters and flashcards are not always available. 45) Audio visual aids are not always used in English classes (because the t-value is not positive).

\section{Discussion}

Results and discussion concern reasons behind the failure of teaching SPINE 5 in Sudan are as follows:

\subsection{Discussion of Teacher Domain Results}

After doing statistical procedure the results were: English language teachers are not specialized in teaching English Language and not qualified enough to cope with SPINE 5, also most of the English Language teachers do not refer to the teacher's book to teach the four skills in their lessons plan, moreover, most of the teachers are not aware of the concept of integrated English curriculum as mentioned in SPINE series or defined by (Humphreys 1981).( Beane, James A. 1977) and (Shoemaker B. 1989), moreover, teachers do not attend and observe lessons to other teachers in their school to develop their performance, these results agreed with Ahmed Gumaa Siddiek (2001) and Faisal Abd Erahman (2007) results.

\subsection{Discussion of Pupils Domain}

The conclusion of statistical results showed that: Pupils' background in English is weak, and they don't find learning English language through SPINE 5 textbook interesting, and can't practice English skills in class or in real life naturally. These results also found by Mahasin Dafalla Mohamed Alhag (2000) and Faisal Abd Erahman (2007).

\subsection{Discussion of Curriculum and Textbook Domain}

Statistical procedure the results and discussion of Curriculum and Textbook Domain showed that Textbook SPINE 5 is too long to be covered in one school academic year, and English language SPINE 5 textbooks are not available for all pupils, add to that the layout of SPINE 5 is neither attractive nor logically organized and doesn't widen pupils' knowledge about western culture, these results are the same results found by Ishraga Bashir Mohammed Elhassan Mahgoub (2001) and Widad Hussein Ibrahim Mohamed (2002).

\subsection{Discussion of Teaching Method Domain}

The statistical procedure the results related to Teaching Method showed that:Teachers don't teach every page in the book and this attributed to crowded class, andthe four skills (listening, speaking, reading and writing) are sometimes taught separately, and the same class is taught by more than one teacher, each teach different skill. These results agree with those found by Widad Hussein Ibrahim Mohamed (2002) and Mohammed Mohammed Abdella Alamin (2007).

\subsection{Discussion of Activities Domain}

The results of the Statistical procedure concerning the activities showed that not all pupils' exercises are not corrected by the teacher and this can be attributed to students' number in the class, this result is similar to Mohammed Mohammed Abdella Alamin (2007) and Ishraga Bashir Mohammed Elhassan Mahgoub (2001) and can be connected to Ahmed Guma'a Siddiek (2004) results about SSC exams.

\subsection{Discussion of Teaching and Learning Environment Domain}

After analyzing statistical results concerning Teaching and Learning Environment Domain, it is clear that teachers do not write supplementary materials to SPINE 5, and classes are crowded and pupils seating is not comfortable and there is a lack of teaching aids do not help free activities these results agree with Mahasin Dafalla Mohamed Alhag (2000), Mohammed Mohammed Abdella Alamin (2007) and Faisal Abd Erahman (2007) results.

\subsection{Conclusion of Finding}

The main conclusion of findings of the study that reflectreasons behind the failure of teaching SPINE 5 In Sudan are:

1) English language teachers are not specialized in teaching English Language and not qualified enough to cope with SPINE 5, also most of the English Language teachers do not refer to the teacher's book to teach the four skills in their lessons plan, moreover, most of the teachers are not aware of the concept of integrated English curriculum as mentioned in SPINE series, and they do not attend and observe lessons to other teachers in their school to develop their performance. 
2) Pupils' background in English is weakand they don't find learning English language through SPINE 5 textbook interesting, and can't practice English skills in class or in real life naturally.

3) Textbook SPINE 5 is too long to be covered in one school academic year, and English language SPINE 5 textbooks are not available for all pupils, also the layout of SPINE 5 is neither attractive nor logically organized and doesn't widen pupils' knowledge about western culture which doesn't reflect the title of the book.

4) English four skills (listening, speaking, reading and writing) are sometimes taught separately and the same class is taught by more than one teacher, each teach different skill and this doesn't enable communicative teaching.

5) Not all pupils' exercises are corrected by the teacher, and this doesn't help pupils to be creative and may be disappointing and demotivating to them.

6) Teachers do not write supplementary materials to SPINE 5, and Pupils seating is not comfortable and lack of teaching aids do not help free activities.

\section{Recommendations}

1) Observation periods must be arranged by English language supervisors to help teachers evaluate and develop each other's performance as well as, also evaluating visits by supervisors should be raised. 2) Employing English language teachers must be according to their qualification and a regular training programme should be set to train English Language teachers to make them aware about what is new in the pedagogy world and it should not be less than three months long. 3) Pupils' standard of English language can be raised by using task-based activities. Activating English Language clubs and societies in schools to improve students' English Language and to encourage them use the language. 4) Every pupil must be provided with a copy of SPINE 5 book in the beginning of the educational year to enable teachers and pupils achieve their tasks. 5) Class-room must not consist of more than 40 students to help using communicative approach. 6) English class periods for SPINE 5 should be increased to 6-7 periods a week to enable the teachers teach each section and activity in the book to develop pupils' English Language. 7) Teach English language through British culture, according to the British environment not Sudanese, and develop teachers' language and ability within British culture training by sending teachers to England to have reinforcing courses in the English heritage not Sudanese or by organizing courses to be taught by British teachers with the collaboration with the British Council in Sudan.

\section{References}

Al Busiri, S. (consultation workshop). (2008). Khartoum Open University of Sudan in collaboration with Cambridge University and higher education and scientific research. Ministry of General Education.

Al Faki, A. B., Ukele, J., Arbab, S., Ismail, S. A. M., \& Hadra, T. O. (1992). The SPINE series for Sudan Teacher book (6). Ministry of Education publications Bureau.

Alamin, M. M. A. (2007). Maintaining English Language Interaction in Large Sudanese Classroom through $C L T$. Khartoum University (Unpublished Doctoral dissertation). Sudan.

Alhag, M. D. M. (2000). The Problem of Fluency in Spoken English Among Students Majority in English Sudanese University (Unpublished Doctoral of Philosophy dissertation). Khartoum University, Sudan.

Beane, J. A. (1977). Curriculum Integration: Designing the Core of Democratic Education. New York: Teachers College Press.

Erahman, F. A. (2007). The Educational Problems Involved in the Teaching of English Language at the basic Level in Bahri Locality from Teachers Point of Views (Unpublished Doctoral of Philosophy dissertation). Alzaim Alazhari University, Sudan.

Humphreys, A., Post, T., \& Ellis, A. (1981). Publishing Center disciplinary Methods: A Thematic Approach. Santa Monica, CA: Goodyear company.

Ismail, S. A. M., \& Cuthert, H. (1997). SPINE 5 Pupil's Book. Ministry of Education Publications Bureau.

Ismail, S. A. M., \& Cuthert, H. (1997). SPINE 5 Teacher's Book. Ministry of Education Publications Bureau.

Ismail, S. A. M., \& Cuthert, H. (1997). The SPINE series for Sudan Teacher book (5). Ministry of Education publications Bureau.

Mahgoub, I. B. M. E. (2001). Analysis of the Sudan Practical Integrated National English Textbook (SPINE 3) (Unpublished Doctoral of Philosophy dissertation). Khartoum University, Sudan.

Mohamed, W. H. I. (2002). English Language Syllabus Versus Time In Secondary Level, A case Study on Spine 5 
(Unpublished Doctoral dissertation). International University of Africa, Sudan.

Shoemaker, B. (Ed.). (1989). Integrative Education: A Curriculum for the Twenty-First Century. Oregon School Study Council 33/2 Good, C.

Siddiek, A. G. (2001). Foreign Language Teacher Training in the Sudan: Past, Present and Strategies for Future Recruitment Policies. International Journal of English Linguistics, 1. http://dx.doi.org/10.5539/ijel.v1n2p115

Siddiek, A. G. (2004). Analysis and Evaluation of Sudan School Certificate English Examination from 2000-2003 (Unpublished Doctoral of Philosophy dissertation). Omdurman Islamic University, Sudan.

Sudan Ministry of Education Report. (2009). Examination Administration.

\section{Appendix 1}

\section{Teachers' Questionnaire}

Dear colleague:

This questionnaire is an instrument of data collection for on-going tilted. Reasons behind the failure of teaching SPINE 5 in Sudan.

I am definitely sure that you would be kind enough to answer all questions in this questionnaire, which will help me to find the final results for this study.

Thanks for your collaboration.

Dr. Mona Mustafa Abdelaziz Hamad

\section{Instructions}

Please read each of the following statements carefully and put a tick $(\sqrt{ })$ in the column (box) of the option which best describes your point of view.

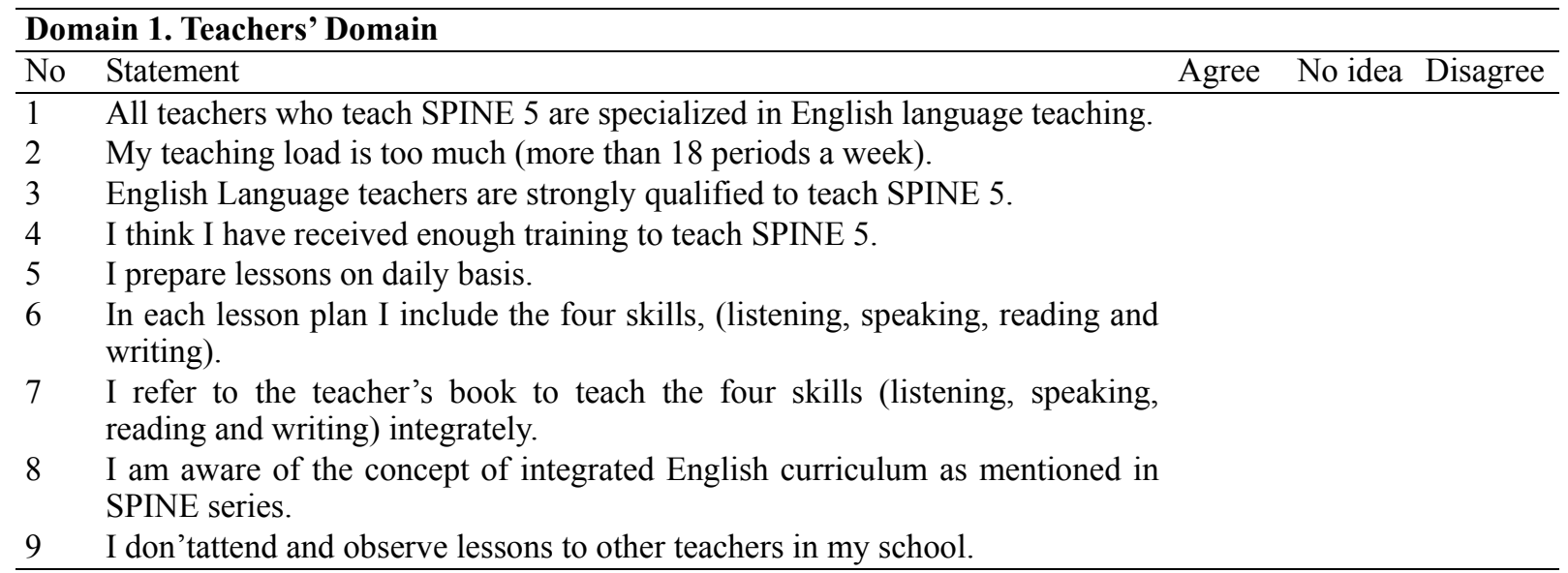

\section{Domain 2. Pupils' Domain}

\begin{tabular}{|c|c|c|c|c|}
\hline No & Statement & Agree & No Idea & Disagree \\
\hline 10 & Pupils' background in English is weak. & & & \\
\hline 11 & Pupils find learning English language through SPINE 5 textbook interesting. & & & \\
\hline 12 & $\begin{array}{l}\text { Pupilscan read and understand English newspapers and simplified stories by } \\
\text { themselves. }\end{array}$ & & & \\
\hline 13 & $\begin{array}{l}\text { Pupilsare encouraged speaking with each other in English language outside } \\
\text { the classroom. }\end{array}$ & & & \\
\hline 14 & Pupils write correct sentences and paragraphs without help. & & & \\
\hline 15 & Pupils listen and understand the dialogues in SPINE 5. & & & \\
\hline 16 & Pupils receive help from their parents at home to practice English with them. & & & \\
\hline 17 & Pupils can understand a foreigner who speaks with them in English. & & & \\
\hline 18 & Pupilsuse English freely and naturally. & & & \\
\hline 19 & Pupils are able to practice English with people outside the school. & & & \\
\hline \multicolumn{5}{|c|}{ Domain 3. Curriculum and Textbook Domain } \\
\hline No & Statement & Agree & No Idea & Disagree \\
\hline 20 & English language SPINE 5 textbooks are available for all pupils. & & & \\
\hline 21 & Teachers make some changes in Spine textbook to suit their pupils'needs or & & & \\
\hline
\end{tabular}


standard.

22 Textbook SPINE 5 is too long to be covered in one school acadmaic year.

23 SPINE 5 is logically organized.

24 The layout of SPINE 5 is attractive.

25 SPINE 5 widens pupils' knowledge about western culture.

\section{Domain 4. Teaching Methods Domain}

\begin{tabular}{|c|c|c|}
\hline No & Statement & Agree $\quad$ No idea Disagree \\
\hline 26 & Teachers use English only to teach the lessons. & \\
\hline 27 & Teachers teach every page in the book. & \\
\hline 28 & Teachers use mixture of English and Arabic in teaching. & \\
\hline 29 & Cassettes are used in teaching listening and speaking skills. & \\
\hline 30 & $\begin{array}{l}\text { The four skills (listening, speaking, reading and writing) are taught } \\
\text { separately. }\end{array}$ & \\
\hline 31 & $\begin{array}{l}\text { The same class is taught by more than one teacher, each teaches different } \\
\text { skills. }\end{array}$ & \\
\hline
\end{tabular}

\section{Domain 5. Activities' Domain}

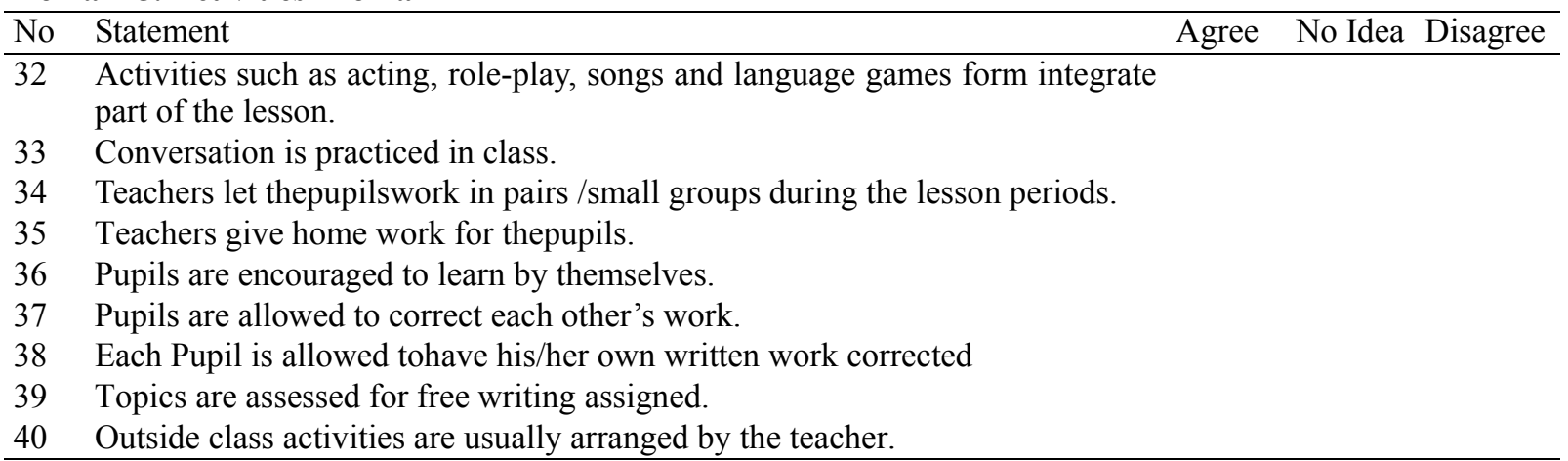

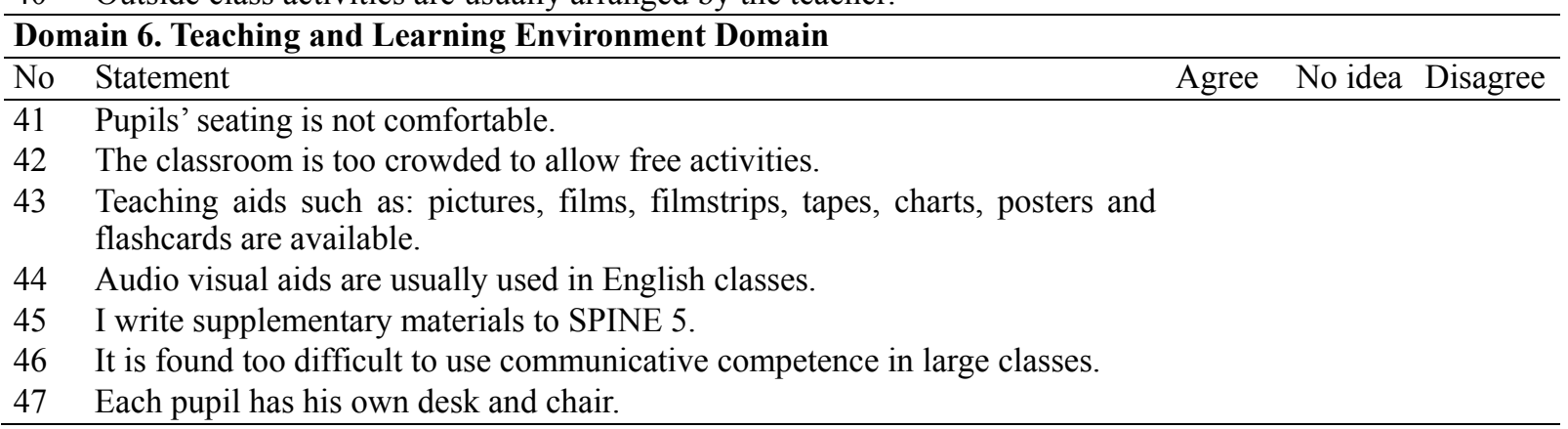

\section{Copyrights}

Copyright for this article is retained by the author(s), with first publication rights granted to the journal.

This is an open-access article distributed under the terms and conditions of the Creative Commons Attribution license (http://creativecommons.org/licenses/by/3.0/). 